Meta

Journal des traducteurs

Translators' Journal

\title{
On Going Beyond the Literal: Translating Metaphorical Conceptualizations in Financial Discourse
}

\section{Laurent Nicaise}

Volume 56, numéro 2, juin 2011

Les corpus et la recherche en terminologie et en traductologie Corpora and Research in Terminology and Translation Studies

URI : https://id.erudit.org/iderudit/1006184ar

DOI : https://doi.org/10.7202/1006184ar

Aller au sommaire du numéro

Éditeur(s)

Les Presses de l’Université de Montréal

ISSN

0026-0452 (imprimé)

1492-1421 (numérique)

Découvrir la revue

Citer cet article

Nicaise, L. (2011). On Going Beyond the Literal: Translating Metaphorical Conceptualizations in Financial Discourse. Meta, 56(2), 407-423.

https://doi.org/10.7202/1006184ar
Résumé de l'article

L'objectif du présent article est de montrer, à l'aide d'un corpus bilingue français-néerlandais, comment des concepts financiers et économiques identiques sont articulés de manière distincte dans les deux communautés linguistiques. Ce travail vise à montrer que comprendre le choix (en l'occurrence, des métaphores) que fait un auteur au sein du répertoire lexical de la discipline devrait aider les apprenants en langue étrangère et les traducteurs à mieux appréhender le discours financier et économique. Cela devrait les sensibiliser au rôle des différences idéologiques, pragmatiques et cognitives entre les langues dans le choix des métaphores. Les données indiquent qu'une analyse de corpus pourrait contribuer à expliquer l'impact de la culture et d'autres variables communicationnelles sur la façon dont les concepts financiers et économiques sont exprimés, sur le plan lexical, dans la presse. 


\title{
On Going Beyond the Literal: Translating Metaphorical Conceptualizations in Financial Discourse
}

\author{
LAURENT NICAISE \\ Free University of Brussels, Brussels, Belgium \\ University of Mons, Mons, Belgium \\ lnicaise@ulb.ac.be
}

\begin{abstract}
RÉSUMÉ
L'objectif du présent article est de montrer, à l'aide d'un corpus bilingue français-néerlandais, comment des concepts financiers et économiques identiques sont articulés de manière distincte dans les deux communautés linguistiques. Ce travail vise à montrer que comprendre le choix (en l'occurrence, des métaphores) que fait un auteur au sein du répertoire lexical de la discipline devrait aider les apprenants en langue étrangère et les traducteurs à mieux appréhender le discours financier et économique. Cela devrait les sensibiliser au rôle des différences idéologiques, pragmatiques et cognitives entre les langues dans le choix des métaphores. Les données indiquent qu'une analyse de corpus pourrait contribuer à expliquer l'impact de la culture et d'autres variables communicationnelles sur la façon dont les concepts financiers et économiques sont exprimés, sur le plan lexical, dans la presse.
\end{abstract}

\section{ABSTRACT}

This article, through a bilingual French-Dutch corpus, looks at how identical financialeconomic concepts are articulated distinctively in the two language communities. The article shows that understanding why an author makes a particular (metaphorical) choice in the lexical repertoire of the discipline could provide language learners and translators with knowledge that will foster their understanding of financial-economic discourse and raise their awareness of ideological, pragmatic and cognitive differences between languages in the role of metaphors. The data indicate that a corpus analysis may contribute to explaining the impact of culture and other communication variables on the lexical realizations of financial-economic concepts in the press.

\section{MOTS-CLÉS/KEYWORDS}

métaphore, discours financier, linguistique de corpus, sémantique cognitive, idéologie metaphor, financial discourse, corpus linguistics, cognitive semantics, ideology

\section{Introduction}

This article reports on and discusses the pedagogical implications of qualitative and quantitative data pertaining to the distribution of metaphorical mapping in two distinct yet closely interrelated language and cultural communities. Recently, researchers in translation studies (See e.g. Vandaele and Lubin 2005 and Schäffner 2004) have proposed that findings in Cognitive Semantics are potentially beneficial to teaching translation: the larger the difference between the ways in which two language communities conceptualize similar experiences, the more difficult the task of translation may become, especially for translators not familiar with the host of variables affecting the selection of metaphors in a particular discourse type. 
It has been demonstrated that the frequent recourse to metaphor in business language may constitute an obstacle for second language learners (Velasco-Sacristán 2005). In addition, in a business environment, the strategies deployed to resolve problems are often regulated by the metaphors to which decision makers and investors have been exposed (Boers 2000). If, for instance, authors/journalists rely on sports metaphors to describe an economic crisis, readers may be induced to infer that the economy could "jump the hurdles" through hard training, expert coaching, sound competition and sacrifices for the team. In American politics, for example, sports metaphors have become a pervasive way of discussing almost any economic or political issue. The sports metaphor, however, is prone to misuse and will often inadvertently meet a language barrier in cross-cultural communication. When top American diplomats commented on the slow progression of negotiations on North Korea's nuclear program in February 2007, they resorted to American football terminology. According to an anecdote recorded by the Associated Press (15/07/07), former Secretary of State Condoleezza Rice declared "This is still the first quarter" and "There is still a lot of time to go on the clock." A few hours later, the head of the U.S. nuclear negotiators, Christopher Hill, described his discussions in Beijing with North Korean officials as follows: "It's always like 3 yards, 3 yards, 3 yards. And then it's always 4 th and 1 , and you make a first down and do 3 more yards."

It hardly needs to be stated that such metaphors may cause insuperable difficulties for translators. It could be argued that including or reinforcing metaphor training in a translation course would increase the students' metaphorical awareness, thus producing more native-like texts when they translate business language. As CharterisBlack (2000) suggests, teaching the language is, at least in part, teaching the conceptual framework of the subject matter. Since referents do not have an undisputable inherent meaning, any choice of representation is in theory replaceable by another lexical choice with different implications. When we choose a particular source domain to realize a concept, we select, consciously or not, a categorization that highlights some of that concept's features and eclipses others.

\section{Aims and method}

The goal of the present article is to show that translator training should attempt to capitalize better on the cultural and conceptual features of these business metaphors.

In this article, as an alternative to corpora involving quite distant business contexts such as the Chinese, English and Spanish stock markets (Chung, Ahrens et al. 2003), or at least as a complementary approach, an approach involving a selection of thematically near-matching content has been taken. Thus a bilingual Belgian corpus was used so as to minimize discrepancies in content while maximizing linguistic, cultural and ideological differences. Despite an almost identical reference framework, the communities represent contrasting linguistic and cultural environments with an increasingly diminishing cultural interaction. This, albeit regrettable, may nonetheless create favourable conditions for studying the cultural limitations of conceptualization. The study is based on a 448 764-word corpus, collected from 967 articles published in the Belgian press in 2005. The corpus includes three Dutch language (De Standaard, De Morgen and Trends-Cash, totalling 413 articles and 223720 words) and three French language newspapers (La Libre Belgique, Le Soir and L'Investisseur, 
totalling 554 articles and 225044 words). The selection was made randomly from all the articles dealing with financial-economic matters in the six newspapers and does not include translated texts. It should also be noted that the articles report basically the same content: the results and share price evolution of Belgian companies quoted on Euronext Brussels and international events that may have an impact on the Belgian economy and financial markets. How metaphors are translated into another language is not evaluated in this study, but rather how the lexical realizations of identical financial-economic concepts in near-parallel news content are distributed in the two linguistic and cultural communities studied is evaluated.

Adopting an onomasiological perspective, which moves from a set of basic financial-economic concepts ${ }^{1}$ to their lexical realizations, makes it possible to contrast the different metaphors used to describe the same concept. The frequencies were obtained by manually tagging and counting occurrences of metaphors and then analyzing the different variables impacting their selection.

In an attempt to compile statistics which could be compared to results generated in other corpus studies, the Metaphor Identification Procedure (MIP), developed recently by the Pragglejaz-group (2007), was applied. The MIP was designed to provide metaphor researchers with a reliable and explicit method for identifying metaphors in various disciplinary and interdisciplinary studies of metaphor. The procedure seeks to determine whether a lexical unit has a more concrete basic meaning that differs from the meaning in the given context and whether the contrast between the two meanings can be understood by comparison. The level of agreement between evaluators was measured by calculating a Cohen's Kappa coefficient, thus repeating a technique exploited successfully by Pragglejaz. The method, applied by three researchers, including the author, to assess agreement across cases on $1 \%$ of the corpus, yielded a Kappa far above the 0.80 threshold for reliable performance.

Source domain identification is a spin-off of metaphor identification. When the primary meaning of a lexical item is consulted in the dictionary (Larousse and van Dale), the lexical field to which this basic meaning belongs is registered and checked against the source domains identified and quantified in recent corpus studies.

The complete data encompass both metaphorical and non-metaphorical lexical items, yet the results reported in the present article only include metaphorical realizations.

The approach is multi-factorial, including variables such as ideology, gender and discourse type, but the present article only concentrates on the impact of the language community factor. The data were submitted to logistical regression analysis, which makes it possible to predict a dichotomous response variable, such as the presence/ absence of WAR metaphors, from a set of independent variables.

Viewed from a cultural perspective, the challenge is to establish how translation studies, which are traditionally oriented toward drawing attention to the similarities and discrepancies between the source and target culture, could address the growing need for efficient communication across borders? It may be proposed that cognitivecultural metaphor research may allow one to discover important features of culturespecific lexis, values and patterns of thought.

A cognitive approach acknowledging the role of embodied experience in thought and language seems an adequate theoretical line of approach to begin investigating the hurdles in intercultural communication. The embodied cognition theory 
advances the idea that embodiment is an essential part of the perceptual and cognitive processes by which we make sense of our experiences in the world. Cognition should therefore be studied in terms of the dynamic interactions between the body and the physical and cultural environment (see e.g., Gibbs 2005).

According to Lakoff and Johnson (1980), a metaphorical process involves experiencing abstract concepts on the basis of predominantly more concrete concepts, although insights from the Blending Theory have shown that metaphorical mapping does not invariably imply a straightforward, unidirectional transfer from source to target domain (Grady, Oakley et al. 1999). Through this process, one or more salient aspects of human experience are highlighted while others are overshadowed. In the same scope of reflection, the Conceptual Metaphor Theory posits that since all cultures are subject to the same physical laws such as gravitation or a host of physiological features of the human body, their experience and representation of the world is guided by universal ontological categories; for instance, orientational concepts include universal schemata such as UP-DOWN, IN-OUT, FRONT-BACK, ON-OFF and DEEP-SHALLOW (Lakoff and Johnson 1980; 1999).

However, as the authors acknowledge, even this unequivocal physical experience does not take place in a cultural vacuum; every experience arises in a cultural environment with particular presuppositions, behaviours and values. Hence, every culture deploys a specific range of concepts to activate universal image schemata. According to Schmidt (2004), such cross-domain mapping may be culture-relevant (i.e., more occurrences in a particular culture) or even culture-specific (i.e., restricted to a particular culture). As a consequence, the most common difficulty in translating metaphor across different business cultures and language communities is not so much the absence of an equivalent metaphorical item in the target language, but rather the evaluation of the mutual relationship between shared and culture-bound constructs when evoking identical concepts (see Snell-Hornby 1995). Hence, insight into cross-cultural conceptualizations may be gained from studying how different cultures and languages resort to different metaphorical expressions to express similar abstract financial-economic concepts.

\section{Analysis and results}

\subsection{Overall distribution of source domains}

Before examining how specific concepts are articulated in both language communities, the global distribution of source domains are shown (Figures 1 and 2). The pie charts show that orientation, food, love, animals, technique, mobility, health, weather, sports, war, and other metaphors are used in Dutch and French corpora. The most frequent metaphorical mappings are then described in detail. 
FIGURE 1

Distribution of source domains in the Dutch-speaking press

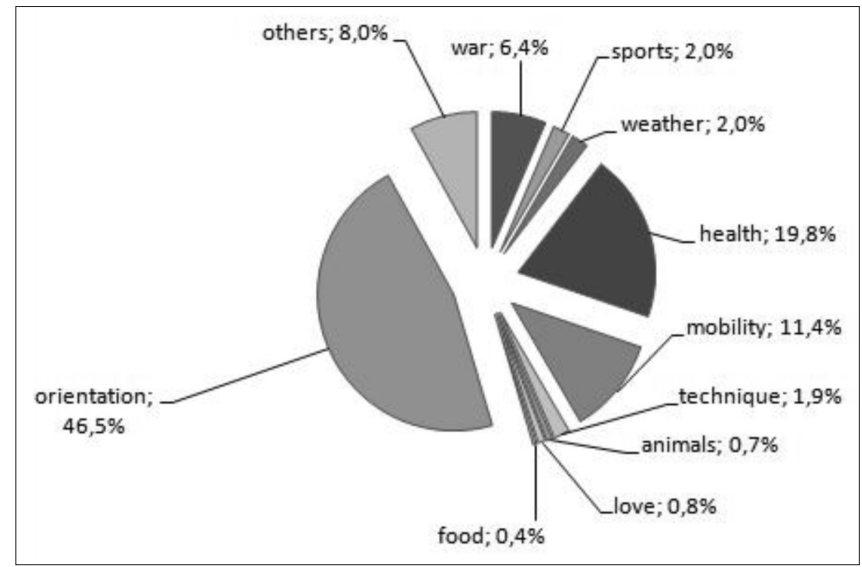

FIGURE 2

Distribution of source domains in the French-speaking press

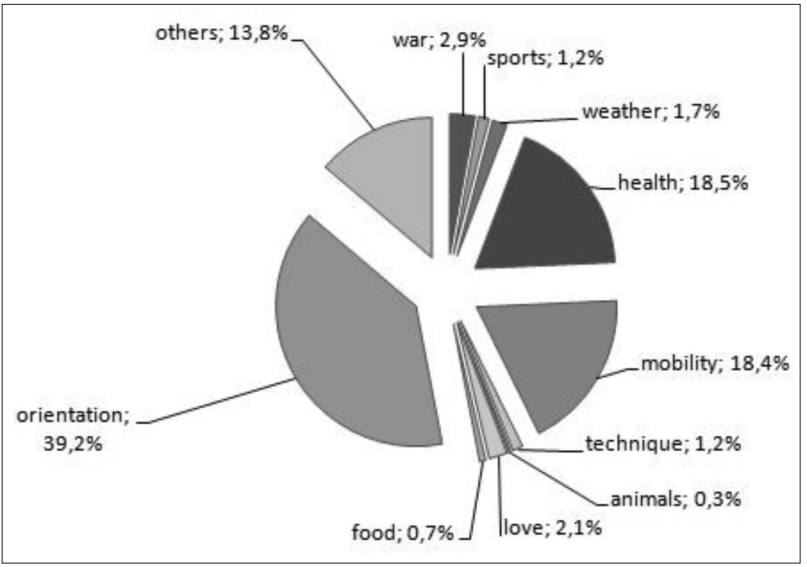

\subsubsection{Orientational metaphors}

The results presented in Figure 1 and 2 indicate that, in both language communities, orientational metaphors are the most frequent category: $46.5 \%$ of all metaphors in the Dutch corpus and 39.2\% in the French corpus. According to Johnson (1999), orientational primary metaphors originate in our bodily interactions with the world and are acquired automatically through our sensomotoric experience from our earliest years. The reason why financial reports appear to be very sensitive to orientational metaphors is that practically any economic parameter can be expressed in terms of rising or falling patterns which can be easily visualized on a chart:

(1) Voor zijn collega Ivan Van De Cloot van ING is het nu wel duidelijk dat de Belgische economie de berg afglijdt.

According to his colleague Ivan Van De Cloot from ING, it is now clear that the Belgian economy is sliding downhill. ${ }^{2}$ 
(2) Le fait marquant de la séance a été la chute de l'action Imperial Chemical Industries, qui a perdu 6,56 pc à 245,75 pence après la publication des résultats du groupe de chimie fine pour le premier trimestre.

The session was marked by the fall of Imperial Chemical Industries, which dropped $6.56 \%$ to 245.75 pence after the fine chemical company announced its first quarter results.

(La Libre Belgique, 06/05/2005)

Such metaphorical orientations are not arbitrary, although the polar oppositions UP-DOWN, FRONT-BACK, etc. are physical in nature, the orientational metaphors based on them may vary from culture to culture. For example, Lakoff (1980) explains that in some cultures the future is coming towards the locutor, whereas in others the locutor is going towards the future. Although some subtle differences between Dutch and French can be sporadically encountered in the corpus, it may be assumed that both language communities are culturally too closely related to deliver substantial differences in the use and distribution of orientational metaphors. Even though ideological and cultural bias may play a conclusive role when orientational metaphors blend with other metaphorical domains, orientational metaphors seem to function on a more or less unintentional psycholinguistic level.

\subsubsection{WAR}

Dutch-speaking journalists appear to use twice as many WAR metaphors as their French-speaking colleagues (Dutch 6.4\%; French 2.9\%):

(3) China staat met Europa en de VS op oorlogsvoet. China is on a war footing with Europe and the US.

(De Morgen, 31/05/2005)

(4) Boeing/Airbus: fin de l'armistice? Boeing/Airbus: end of the ceasefire?

(La Libre Belgique, 12/04/2005)

Logistical regression analysis (oR 2.61) confirms the strength of the relationship between the language community and the use of WAR metaphors and shows that this is a more decisive factor than, say, ideology. The prevalence of WAR metaphors in describing financial situations in the Dutch-speaking press constitutes a stimulus for a discussion regarding the extent to which some of these COMBAT metaphors could be attributed to societal values and preoccupations.

\subsubsection{HEALTH}

HEALTH metaphors appear to display similar frequencies on both sides of the language border: $19.8 \%$ in the Dutch corpus and $18.5 \%$ in the French corpus. Logistical regression analysis substantiates that the language community does not play a significant role.

Physical and mental health is a powerful ontological metaphor in economic reports. Economic growth, profit accumulation and increasing share prices are considered a sign of health and vitality, whereas stagnation and decreasing share prices are believed to be symptoms of poor health: 
(5) Het tegenvallende banenrapport in de VS werd vrijdag nog geïnterpreteerd als een slecht teken voor de gezondheid van de Amerikaanse economie.

The worse-than-expected job report in the US was interpreted as a bad omen for the health of the US economy.

(De Standaard, 08/02/2005)

(6) L'économie tousse, la pub s'enrhume.

The economy is coughing and the advertising market is getting a cold.

(La Libre Belgique, 08/04/2005)

Because health is so precious, health care is often given priority over other aspects of life. This inference may be preserved in the conception of economics under this metaphor (Charteris-Black and Musolff 2003). Using HEALTH metaphors in a translation may entail that, most of the time, the patient could not be held responsible for the disease. As a consequence, attention is usually focused on the treatment, not on the underlying causes of the problem (Boers and Demecheleer 1995). This could, at times, be a convenient excuse for public support for a host of measures that would be politically unacceptable in normal circumstances:

(7) In tegenstelling tot zijn Amerikaanse concurrenten wordt Toyota niet verlamd door zware pensioens- en gezondheidsbijdragen.

Unlike its American competitors, Toyota is not paralyzed by heavy retirement and health insurance contributions.

(Trends Cash, 31/10/2005)

(8) Telindus s'allège pour contrer Belgacom. Le management de Telindus promet plus de 4 euros par action à ses actionnaires. Comment? En vendant ses actions Mobistar et des bâtiments et en allégeant ses activités non rentables.

Telindus is slimming down to counter Belgacom. Telindus management has promised more than 4 euros a share to its shareholders. How? By selling its stake in Mobistar and property and by reducing the weight of its cost-ineffective activities.

(La Libre Belgique, 25/10/2005)

\subsubsection{MOBILITY}

MOBILITY metaphors appear to be more frequent in the French language press (18.4\%) than in the Dutch language press (11.4\%). Regression analysis corroborates these percentages (OR Dutch/French 0.53) and further brings to light that the frequencies of MOBILITY metaphors are superior in the free-market oriented (OR 2.25) and conservative (OR 1.99) press. Indeed the free-market oriented weekly journal L'Investisseur has the highest frequency of MOBILITY metaphors (21.6\%), while the centre-left daily newspaper Le Soir makes a more modest contribution (10.9\%).

Most of these MOBILITY metaphors are based on image schemata that arise out of a physical experience within space and time (Lakoff 1987). Economic policy is increasingly perceived as a never-ending movement along a path towards a fictive destination (Boers 1997). The metaphor implies that moving forward quickly is propitious, while slowing down or moving backward is detrimental:

(9) Les actions de croissance «large cap» sont restées à la traîne ces dernières années. "Large cap" growth values have been lagging behind in recent years.

(La Libre Belgique, 22/12/2005) 
(10) Intel a pris une grande longueur d'avance sur le marché des ordinateurs portables. Intel is leading the race of the laptop market.

(La Libre Belgique, 19/03/2005)

Moving along the virtual path of the economy can be carried out through different means of transportation. Each means of transport has its own strengths and weaknesses, as well as distribution along the linguistic border. The French language press uses more CAR (3 occurrences in the Dutch corpus; 10 in the French corpus) and AIRPLANE (Dutch 23 occurrences; French 38) metaphors, while the BOAT (Dutch 38 occurrences; French 13) and TRAIN (Dutch 17 occurrences; French 11) metaphors are more widespread in the Dutch language press:

(11) De telecombedrijven kapseisden bijna onder het gewicht van hun schulden. The Telecom companies almost capsized under the weight of their debts.

(Trends Cash, 09/03/2005)

(12) L'économie américaine devrait connaître un «atterrissage en douceur» au cours de la deuxième moitié de l'année 2006.

The US economy should make a soft landing in the second half of 2006.

(La Libre Belgique, 21/12/2005)

(13) De Duitsers zetten zich op kop, kleinere landen als België en Nederland koppelden hun wagon aan en profiteerden mee van de Duitse slagkracht. Na de Duitse eenmaking in 1990 begon de locomotief te sputteren.

The Germans were in front, while smaller countries like Belgium and the Netherlands were coupling their railway carriages to benefit from the German power. After the German reunification in 1990 the locomotive started to sputter.

(De Morgen, 27/08/2005)

\subsubsection{SPORTS}

Sport plays a vital role in our society, creating social capital and exuding dynamism, youth and health. Both in sports and society, individuals are encouraged to perform strongly, while weak performances are punished. According to this metaphorical model, markets and economies are viewed as a highly competitive, zero-sum game environment, with winners and losers, where performance and speed play a key-role:

(14) China heeft in afwachting van de Olympische Spelen in Peking zelfs al enkele records gebroken.

In anticipation of the Olympic Games in Beijing, China has already broken several records.

(Trends Cash, 16/06/2005)

(15) Option remporte une nouvelle fois, après sa performance en 2003, le trophée de la plus forte croissance.

Option has once again won the trophy for the strongest growth, after its performance in 2003.

(L'Investisseur, 04/01/2005)

In the corpus, SPORTS metaphors generally retain the aspect of natural fighting and animosity, albeit in a less bloody variant. SPORTS and GAME metaphors usually contain a blending of competition and playfulness, which can both reinforce and mitigate the dominant WAR scheme (Koller 2003). The two domains overlap to some extent, as shown by the numerous cases of polysemy in football reports (Jansen and Sabo 1994). Although not always relevant from a synchronic point of view, many 
SPORTS terms derive from the field of war (Malszecki 1995). This etymological background of many sports terms is an indication of the conceptual connections between SPORTS and WAR. Given their predilection for WAR imagery, it is thus not surprising that Dutch language journalists (2\%) use more SPORTS metaphors than their French language colleagues (1.2\%), although this source domain is less widespread than hypothesized and indeed below the frequencies observed by Koller (2004) in Anglo-Saxon newspapers. This again underscores the culture-bound aspect of metaphorical choices. Furthermore, the alleged effect of the language community on the use of SPORTS metaphors cannot be convincingly substantiated by logistical regression analysis.

Which sports are addressed is also a matter of culture. For example, CYCLING metaphors are retrieved almost exclusively in the Dutch language press: 16 occurrences compared to only one highly conventional metaphor in the French language press. Indeed, cycling draws on a rich tradition in the history of Flemish sport. The erstwhile cycling champions, "the Flandriens," were a tough, unsophisticated generation of Flemish riders, far removed from the ostentatious media world of the Tour de France. These sportsmen, who are legends in their native Flanders, are still role models for young upcoming cyclists. CYCLING metaphors are often related to the concept of RACE, a prevalent notion in financial reports:

(16) De sterke klim van het aandeel CFE dit jaar heeft de allures van de Col du Galibier. Het komt er op aan om te weten of CFE direct zal kunnen doorklimmen naar Alpe d'Huez, of als er daarvoor een kleine afdaling komt.

The strong climb of CFR this year looks like the Col du Galibier. The question now is whether CFE will immediately climb further to Alpe d'Huez or cycle down the mountain a little bit.

(Trends Cash 15/12/2005)

(17) Onze economie fietste vorig jaar in de kopgroep van de eurozone, maar moet nu de rol lossen.

Last year, our economy cycled in the break away group but is now lagging behind.

(De Morgen 28/05/2005)

Hitherto, both in economic theory and in the financial reports analyzed here, the zero-sum logic, according to which one participant's gain or loss is exactly balanced by the losses or gains of the other participant(s), is not really questioned, overshadowing other cooperative features of sports, such as fair play and teamwork (Lilien and Kotler 1983). SPORTS metaphors appear to be highly useful in articulating a strictly competitive economic framework. If the total profits of companies and national economies are aggregated, and the total losses are subtracted, they will come to zero (Thurow 1985).

However, most economic situations do not conform to the zero-sum metaphorical model. It may be defended that the essence of any commercial exchange lies in the assumption that all participants in a voluntary transaction believe that they will be better off after the trade than before, otherwise they would not participate. Even though it is not always the case that every party will benefit equally, a voluntary commercial exchange will always yield a non-zero-sum outcome whenever the result is a net gain, regardless of how evenly or unevenly that gain is distributed. 


\subsubsection{ANIMALS}

The animal world is a non-negligible source of inspiration for financial journalists, although the frequencies on both sides of the linguistic and cultural border are largely inferior to other source domains: $0.7 \%$ for the Dutch language press and $0.3 \%$ for the French language press. In financial reports, two animals play a prominent role: the bull and the bear. Bull markets are characterized by investor confidence, whereas bears expect that the market will yield negative returns. Both metaphors probably originate from the way in which the animals attack their opponents. A bull thrusts its horns up into the air while a bear swipes its paws down, thus symbolizing upward and downward trends:

(18) Voor een aandelenbeurs waar beleggers al meer dan een decennium geplaagd worden door een verschrikkelijke berenmarkt is dat een kristalhelder signaal: Japan heeft de beer verslagen.

This should be a clear signal to a stock market where investors have been tormented by an appalling bear market for more than a decade: Japan has defeated the bear.

(De Standaard, 18/11/2005)

(19) Depuis une grosse semaine, les «haussiers» et les «baissiers» se disputent violemment la domination des Bourses. Le bras de fer du taureau et de l'ours.

For more than a week, the markets have been torn by upward and downward forces. The fight between bulls and bears has started.

(Le Soir, 23/04/2005)

In both language communities, ANIMAL imagery may emphasize some desirable aspects of natural selection:

(20) Tekenend voor de gezondheid van de overnamemarkt is dat overnemers niet meer bestraft worden wanneer ze een grote prooi binnenhalen, iets wat in minder exuberante tijden wel vaker gebeurt.

Illustrative of the strength of the takeover market is that buyers are no longer punished when they capture a large prey, which would otherwise be the case in less exuberant times.

(De Standaard, 07/09/2005)

On the other hand, the same imagery can be used to criticize the presumably ruthless features of financial predators:

(21) La plupart des fonds en "private equity» ont des portefeuilles avec une durée de vie limitée (en général 10 ans). Il y aurait même une pensée unique: prendre la majorité du capital (pour être sûr de pouvoir vendre à tout moment), contracter beaucoup de dettes et rester au maximum trois ans. [...] Ils donnent même parfois l'impression d'être des vautours affamés prêts à se jeter sur leur proie.

Most private equity funds have a short lifespan (generally 10 years). They seem to pursue a common goal: take a majority stake (to make sure they can sell at any time), accumulate debts and stay for a maximum of 3 years. [...] They even look like starving vultures ready to attack their prey.

(La Libre Belgique, 11/07/2005)

\subsubsection{ROMANCE}

ROMANCE metaphors seem to be at odds with the dominant metaphorical models of WAR and MOBILITY. The MARRIAGE metaphor suggests that emphasizing trust 
in business relationships should increase effectiveness (Hunt and Menon 1995). In particular, take-over bids are often portrayed as a mating game:

(22) De twee reuzen uit de consumentenbranche kennen elkaar van eerdere toenaderingspogingen. Sinds die laatste flirt is het landschap in de sector danig veranderd. The two retail giants know each other from earlier romantic overtures. Since this last flirtation, the sector has experienced profound changes.

(Trends Cash, 31/01/2005)

(23) Thijs croit encore au mariage. Un seul consortium (le groupe financier CVC allié à la poste danoise) resterait en lice.

Thijs still believes in a marriage. According to rumours, there remains only one marriage candidate, a joint-venture between financial group CVC and the Danish Post.

(La Libre Belgique, 30/06/2005)

The seduction attempt can result in a marriage or a rejection:

(24) De Post stapt in het huwelijksbootje. Het langverwachte huwelijk werd gisteren bezegeld en moet De Post klaarstomen voor de verdere vrijmaking van de postmarkten in Europa.

The Belgian Post is getting married. The long-awaited marriage was sealed yesterday and should prepare the Belgian Post for the next steps in the liberalization of the postal markets in Europe.

(De Morgen, 13/10/2005)

(25) Dexia repousse les avances de Fortis.

Dexia rejects Fortis' advances.

(La Libre Belgique, 23/09/2005)

According to O'Malley and Tynan (1999), the potential impact that a more frequent use of the ROMANCE metaphor may have on the economic science should not be underestimated. By developing relationships based on trust and commitment, uncertainty may be reduced, assets joined and costs shared, while problem solving becomes more efficient. This would be expected to result in more wealth creation.

The data suggest that in the Dutch language press, ROMANCE metaphors are not in a position to threaten the dominance of WAR metaphors; only $0.8 \%$ compared to twice as many $(2.1 \%)$ in the South of Belgium. Regression analysis corroborates that the Dutch language press is particularly unromantic (OR 0.14).

\subsubsection{WEATHER}

The similarities between the weather and the markets are conspicuous; both domains are considered capricious and unpredictable. Even though their predictions are based on extensive research, both weather and financial experts will deliver projections on the basis of variables that are constantly changing. Obviously, a positive evolution of the financial indicators is associated with favourable weather conditions and vice versa:

(26) Dollar faible, croissance léthargique: les Bourses redeviennent hésitantes. Le temps se couvrirait-il?

Weak dollar and lethargic growth: the markets begin to hesitate again. Is the sky getting cloudy? 
(27) Vooruitzichten voor Europa: bewolkt met hier en daar een opklaring. Forecast for Europe: cloudy with a few sunny spells.

(Trends Cash, 03/01/2005)

The frequent use of metaphors of WEATHER or NATURAL DISASTERS may imply that financial and economic crises are ineluctable and that the malefactors must be identified outside the system or establishment. If economic crises are perceived in terms of weather disorders, this may imply a vision of the economy as the "victim" of natural forces independent of human action:

(28) In de afgelopen tien jaar werden onder meer Mexico, Rusland, Thailand, ZuidKorea, Indonesië en Argentinië met orkaankracht getroffen.

In the past ten years, Mexico, Russia, Thailand, South-Korea, Indonesia and Argentina have been hit by hurricane-force winds.

(De Standaard, 08/01/2005)

(29) En une semaine, les grandes bourses internationales ont connu des changements atmosphériques qui semblaient être le monopole de notre météo nationale: des giboulées, conduites par les investisseurs «baissiers» (symbolisés aux Etats-Unis par un ours) immédiatement suivies par de superbes éclaircies, menées par les «haussiers» (taureau).

In a week's time, the major international markets have been experiencing weather changes that seemed to be the monopoly of our national weather: rainstorms, brought on by bearish investors, followed by some magnificent spells of sunshine, led by the bulls.

(Le Soir, 23/04/2005)

WEATHER metaphors are distributed almost equally on both sides of the linguistic and cultural border (DUTCH 2\%; FRENCH 1.7\%). Regression analysis indicates that the language community does not have a significant impact on the selection of WEATHER metaphors, since the odds ratio does not meet the 0.01 significance level.

\subsection{Specific concepts}

\subsubsection{TAKE-OVER}

The data show that WAR (38.3\%) and LOVE (39.8\%) metaphors are used with the same frequency when the concept TAKE-OVER is realized, eclipsing all the other domains. Yet, the results indicate that French language journalists tend to associate TAKE-OVER BIDS with love scenes $(59.8 \%$ of the total number of metaphors used to describe the TAKE-OVER concept in the French corpus), while their Dutch language colleagues seem to prefer WAR imagery (46.2\%):

(30) Euronext demande la main du LES.

Euronext has asked for LES's hand in marriage.

(La Libre Belgique, 10/02/2005)

(31) De banken zullen de eigen oorlogskas van Euronext bijspekken, mocht het tot een heuse biedoorlog komen met de beurs van Frankfurt.

The banks will build up their war chest in case a bid war with the Frankfurt Bourse breaks out. 
In both languages, the majority of WAR metaphors are highly conventional. This could, at least in part, be explained by the circumstances in which journalists are forced to work where there is insufficient time to process the information, so they need to rely on conventional metaphors. Yet, according to Holmgreen (2003), the frequent use of WAR metaphors is, although conventional, remarkably consistent with a free-market political agenda, as readers are encouraged to blame perpetrators outside the system for a crisis rather than the system itself. However, on the basis of linguistic material alone, it is difficult to establish objectively whether the abundance of military imagery in the Dutch language press may be linked to the current sociopolitical climate in Flanders, which tends to be characterized by a right-wing, conservative bias, compared to the South of Belgium, with its successive coalitions of left-wing parties, adopting a more community-based view.

\subsubsection{RESTRUCTURING}

When the concept of RESTRUCTURING is introduced, the French language press experiences the context more often as a FIGHT (11.5\%) than the Dutch language press $(1.6 \%)$, while the latter has in turn a preference for HEALTH metaphors $(68.3 \%$ compared to $53.8 \%$ for the French language press). It is again delicate to associate these metaphorical differences to cultural variation, yet it may be argued that the French language press tends to perceive staff-reducing reorganizations as traumatic and aggressive, while Dutch language journalists are more inclined to focus on the need for reforms to guarantee the "company's health":

(32) Par contre, Sony a supprimé 10000 emplois et a lancé un "plan de guerre» dans l'espoir de retrouver sa splendeur passée.

However, Sony has cut 10000 jobs and launched a "military plan" to recover its past glory.

(La Libre Belgique, 31/12/2005)

(33) Met de sluiting van Fabelta Ninove start de textielsector het nieuwe jaar in mineur. Het is de zoveelste etappe in de sanering van de Vlaamse textielindustrie. Een pijnlijk proces, maar onvermijdelijk in het licht van de toegenomen internationale concurrentie.

The new year has not started well for the textile industry, with the closure of Fabelta Ninove. It is the latest step in the healing of the Flemish textile industry. This is a painful, yet inescapable process in light of the increased international competition.

(De Standaard, 12/01/2005)

(34) Afgeslankt Carestel neemt nieuwe start.

Slimmed-down Carestel takes a new start.

(De Standaard, 11/05/2005)

\subsubsection{DAILY SHARE PRICE EVOLUTION}

The predilection of Dutch language journalists for WAR metaphors (3.5\% compared to $0.7 \%$ for the French corpus) is clearly seen in the realization of the concept of DAILY SHARE PRICE EVOLUTION. Moreover, Dutch language journalists use twice as many SPORTS metaphors (2\%) as their French language colleagues (1\%), who seem to prefer MOBILITY metaphors (French 17.5\%; Dutch 7.4\%): 
(35) Aan de kop van het peloton vinden we de Nederlandse financiële dienstverlener ING, geleid door de Belg Michel Tilman.

At the front of the peloton, we find the Dutch financial services group ING, led by the Belgian Michel Tilman.

(Trends Cash, 04/02/2005)

(36) Cet indice qui évoluait autour de 280 points depuis un an, a décollé à la fin février pour dépasser les 300 points.

After fluctuating around 280 points for a year, the index took off at the end of February to climb above 300 points.

(La Libre Belgique, 18/03/2005)

Not surprisingly, orientational metaphors abound in both language communities (Dutch 68.8\%; French 53.6\%):

(37) La forte hausse du prix du plomb constituait une agréable surprise pour Campine. The strong rise in the lead price was a nice surprise for Campine.

(Trends Cash, 04/01/2005)

(38) In Frankfort daalde de chemiegroep Bayer met 2,6\% tot 24,11 euro. In Frankfurt the chemical concern Bayer fell by 2,6\%, down to 24.11 euro.

(De Standaard, 06/01/2005)

\section{Discussion}

An intriguing question is to what extent the political and ideological bias of both linguistic and cultural communities has an impact on metaphor selection. A satisfactory answer to this question would need, at the very least, an in-depth socio-semantic survey that exceeds the scope of this study. However, by adopting an onomasiological approach, and taking into consideration all the metaphorical realizations of the same concept, one may be able to reveal to a certain degree the culture-bound aspect of particular metaphorical models.

There seems to be a manifest distinction between "shared" and culture-bound metaphors. Although the Dutch press seems to employ slightly more orientational metaphors, the use of the main aspects of these metaphors appears to be nearly identical. Not only highly conventional primary metaphors as stijgen/monter (rise) or dalen/descendre (go down), but also somewhat more complex metaphors as tuimelen/culbuter (tumble) are almost translation equivalents and display analogous frequencies. These results seem to corroborate Lakoff and Johnson's (1999) claim that orientational metaphors belong to the core of conceptual metaphors that we use in our everyday life, as the cognitive value of orientational metaphors exceeds any differences between the two linguistic and cultural communities studied here. CharterisBlack and Musolff (2003) conclude rightly that this is not, then, an area in which second language instruction and a translation course need to give explicit focus.

The data further suggest that the two cultures or language communities have their own metaphorical preferences with regard to specific source domains, even for describing identical situations. It could be inferred from this that effective communication in a multilingual environment requires awareness of these metaphorical implications. When a source domain is more productive in the source language, translators may benefit from increased metaphorical awareness.

Equipping translators with an increased conceptual competence may thus contribute to problem-solving strategies. As cultural mediators, translators play a key-role 
in bridging cultural gaps. Conceptual metaphors constitute one of the most problematic obstacles in translation as conceptual differences between languages frequently lead to producing unnatural translations in the target language. This certainly applies to the translation of financial texts, in which culture-bound metaphors are particularly abundant (Fuertes-Olivera 1998). The degree of difficulty is determined by the degree to which the metaphorical systems of source and target languages overlap. Even closely related languages can show discrepancies on a metaphorical level despite intense cultural contact and the globalization of the economy. Inadequate knowledge of these metaphorical ramifications might have negative consequences for the career of translators, while a better understanding of similarities and differences in metaphor use between languages could lead not only to better translations but also to improved contacts in a bi- or multicultural context.

\section{Concluding remarks}

Translating a document is a race against the clock, since the original author has in theory more time to reflect on style, metaphor and cohesiveness. As a consequence, even well-trained translators may have to resort more often to stereotyped metaphors, not always realizing how these metaphors filter the reader's perception of reality and may act as a brake on alternative views, which may have undesirable effects on readers' and investors' decisions. It is likely that language and translation training may benefit from a cognitive-cultural analysis of how the members of a given linguistic community use metaphors to reflect their attitudes towards the world in general and the life of their community in particular. It can be concluded that drawing on the cognitive framework described here may help place the translator in a better position to produce conceptually adequate texts in the target language.

\section{NOTES}

1. DAILY SHARE PRICE EVOLUTION, SHORT-TERM TREND, ECONOMIC SITUATION, EVOLUTION OF THE COMPANY RESULTS, COMPETITION, RESTRUCTURING and TAKEOVER BID.

2. The examples have been translated by the author into English to show the differences in metaphorical conceptualizations between Dutch and French.

\section{REFERENCES}

Boers, Frank (1997): Health, fitness and mobility in free market ideology. In: Marc MAUfort and Jean-Pierre van Noppen, eds. Voices of Power. Lièges, Belgium: Belgian Association of Anglicists in Higher Education, 89-96.

BoERs, Frank (2000): Enhancing metaphoric awareness in specialised reading. English for Specific Purposes. 19(2):137-147.

Boers, Frank and Demecheleer, Murielle (1995): Travellers, patients and warriors in English, Dutch and French economic discourse. Belgisch Tijdschrift voor Filologie en Geschiedenis. 73(3):673-691.

Charteris-Black, Jonathan (2000): Metaphor and vocabulary teaching in ESP economics. English for Specific Purposes. 19(2):149-165.

Charteris-Black, Jonathan and MusolfF, Andreas (2003): 'Battered hero' or 'innocent victim'? A comparative study of metaphors for euro trading in British and German financial reporting. English for Specific Purposes. 22(2):153-176. 
Chung, Siaw Fong, Ahrens, Kathleen and Yahui, Sung (2003). STOCK MARKETS AS OCEAN WATER: A Corpus-based, Comparative Study in Mandarin Chinese, English and Spanish. Proceedings of the 17th Pacific Asia Conference on Language, Information and Computation (PACLIC), Singapore, 1-3 October 2003. 124-133. Visited 12 December 2009, < http://www. kathleenahrens.com/images/Stock_Markets_As_Ocean_Water-_A_Corpus-based,_Comparative_Study_of_Mandarin_Chinese,_English_and_Spanish.pdf $>$.

Fuertes Olivera, Pedro (1998): Metaphor and translation: A case study in the field of Economics. In: Purificación Fernández Nistal and José María Bravo Gozalo, eds. La Traducción: Orientaciones Lingüisticas y Culturales. Valladolid: Servicio de Apoyo a la Enseñanza, 79-95.

Gibbs, W. Raymond, jr. (2005): Embodiment and cognitive science. Cambridge: Cambridge University Press.

Grady, Joseph, OAkley, Todd and Coulson, Seanna (1999): Blending and Metaphor. In: Gerard Steen and Raymond Gibbs, eds. Metaphor in Cognitive Linguistics. Current Issues in Linguistic Theory. Amsterdam: John Benjamins, 101-124.

Holmgreen, Lise-Lotte (2003): Setting the neo-liberal agenda: How metaphors help shape socio-economic "realities." In: Martin DöRING, ed. Metaphorik.de. 5:90-115.

Hunt, Shelby and Menon, Anil (1995): Metaphors and competitive advantage: evaluating the use of metaphors in theories of competitive strategy. Journal of Business Research. 33(2): 81-90.

Jansen, Sue Curry and SABo, Donald (1994): The sport/war metaphor: Hegemonic masculinity, the Persian Gulf War, and the New World Order. Sociology of Sport Journal. 11(1): 1-17.

JoHnson, Christopher (1999): Constructional Grounding: The Role of Interpretational Overlap in Lexical and Constructional Acquisition. Doctoral dissertation, unpublished. Berkeley: University of California.

Koller, Veronika (2003): Metaphor Clusters in Business Media Discourse: A Social Cognition Approach. Doctoral dissertation, unpublished. Vienna: University of Vienna. Visited 31 July 2011, <http://citeseerx.ist.psu.edu/viewdoc/download?doi=10.1.1.86.8386\&rep=rep1\&type=pdf $>$.

Koller, Veronika (2004): Metaphor and Gender in Business Media Discourse: A Critical Cognitive Study. Hampshire, England: Palgrave Macmillan.

Lakoff, George and Johnson, Marc (1980). Metaphors We Live By. Chicago: Chicago University Press.

Lakoff, George and Johnson, Marc (1999): Philosophy in the Flesh: The Embodied Mind and its Challenge to Western Thought. New York: Perseus.

Lakoff, George (1987): Women, Fire and Dangerous Things: What Categories Reveal about the Mind. Chicago: Chicago University Press.

Lilien, Gary and Kotler, Philip (1983): Marketing Decision Making: A Model-Building Approach. New York: Harper Row.

Malszecki, Gregory (1995): 'He shoots! He scores!': Metaphors of War in Sport and the Political Linguistics of Virility. Doctoral dissertation, unpublished. North York: York University.

O'Malley, Lisa and Tynan, Caroline (1999): The Utility of the Relationship Metaphor in Consumer Markets: A Critical Evaluation. Journal of Marketing Management. 15(7):587602.

Pragglejaz Group (2007): MIP: A method for identifying metaphorically used words in discourse. Metaphor and Discourse. 22(1):1-39.

Schäffner, Christina (2004): Metaphor and Translation: Some Implications of a Cognitive Approach. Journal of Pragmatics. 36(7):1253-1269.

SснміDт, Christopher (2004): The relevance of culture-specific conceptualisation for organisational management: a cross-cultural study on the difference between German and Swedish organizational concepts. Electronic Journal Intercultural Communication. 7. Visited 31 July 2011, <http://www.immi.se/intercultural/nr7/schmidt-nr7.doc>.

Snell-Hornby, Mary (1995): Translation Studies: An Integrated Approach. Amsterdam: John Benjamins. 
Thurow, Lester (1985): The Zero-sum Solution: Building a World-class American Economy. New York: Simon and Schuster.

VAndaele, Sylvie and Lubin, Leslie (2005): Approche cognitive de la traduction dans les langues de spécialité: vers une systématisation de la description de la conceptualisation métaphorique. Meta: Translators' Journal. 50(2):415-431.

VelasCo-SACRistán, Marisol (2005): Metaphor and ESP: metaphor as a useful device for teaching L2 Business English learners. Ibérica. 10:115-131. 